\title{
О КРИТЕРИЯХ ОПРЕДЕЛЕНИЯ РАЗМЕРА КОМПЕНСАЦИИ МОРАЛЬНОГО ВРЕДА, ПРИЧИНЕННОГО ВСЛЕДСТВИЕ ЭКОЛОГИЧЕСКИХ ПРАВОНАРУШЕНИЙ
}

\begin{abstract}
Аннотация: В статье раскрывается вопрос о критериях определения размера компенсачии морального вреда, причиненного вследствие экологических правонарушений. Актуальность работы обусловлена наличием в законодательстве Российской Федерачии открытого перечня критериев определения размера компенсации морального вреда, а также новизной исследования. При этом особенности морального вреда, причиненного вследствие экологических правонарушений, позволяют выявить и дополнительные критерии определения размера компенсации морального вреда, причиненного вследствие экологических правонарушений.
\end{abstract}

Ключевые слова: Юриспруденщия, Правонарушение, Вред, Страдания, Размер, Критерии, Право, Экология, Суд, Компенсачия

ложной задачей при компенсации морального вреда, причиненного вследствие экологических правонарушений, является определение размера компенсации. По замечанию А. М. Эрделевского, анализ законодательства и судебной практики России и ряда зарубежных стран показывают большое сходство проблем, возникающих при применении института компенсации морального вреда ${ }^{1}$. Обращает на себя внимание отсутствие законодательного регулирования института компенсации морального вреда не только в странах прецедентного права, где это предопределяется особенностями самой правовой системы, но и в странах статутного права. Существенную роль играют судебная практика и доктринальные толкования, прослеживается тенденция к упорядочению систем определения размеров компенсации ${ }^{2}$.

\footnotetext{
${ }^{1}$ См.: Эрделевский А. М. Компенсация морального вреда // Анализ и комментарий законодательства и судебной практики (3-е издание). - М.: Волтерс Клувер, 2007. - С. 200-201.

2 Известны три подхода к компенсации морального вреда в англо-американской системе права: концептуальный, личностный и функциональный. Концептуальный подход основывается на аналогии с имущественным ущербом: каждое повреждение части тела, нарушение функции организма оценивается как имущественный вред и, таким образом, имеет денежный эквивалент (правоприменительной практикой выработана своеобразная «тарифная система», с помощью которой определяется размер компенсации вреда, причиненного здоровью). Личностный подход заключается
}

Исходя из правил ст. ст. 151, 1101 Гражданского кодекса Российской Федерации размер компенсации морального вреда определяется судом в зависимости от: характера (степени) причиненных потерпевшему физических и нравственных страданий, связанных с индивидуальными особенностями лица, которому причинен вред; степени вины причинителя вреда в случаях, когда вина является основанием возмещения вреда; иных заслуживающих внимания обстоятельств (другие обстоятельства, имеющие значение для рассмотрения заявленных требований) ${ }^{3}$.

\footnotetext{
в том, что степень или глубина страданий, переживаний, вызванных повреждением здоровья, оценивается в зависимости от особенностей личности (в судебной практике США к дополнению к этому подходу применяли временной принцип оценки страданий для определения размера морального вреда). Функииональный подход имеет место тогда, когда личностные свойства потерпевшего не проявляются достаточно четко и невозможно установить «ценность» счастья для этого лица (суд исходит из собственного убеждения в том, какую именно назначить сумму, чтобы она оказалась достаточной потерпевшему для его разумного утешения) / См. об этом: Горшенков Г. Г. Моральный вред и его компенсация по российскому законодательству. Дисс. ... канд. юрид. наук. - Новгород, 1990. - С. 102-105.

${ }^{3}$ Постановление Пленума Верховного Суда РФ от 18 октября 2012 г. № 21 «О применении судами законодательства об ответственности за нарушения в области охраны окружающей среды и природопользования» // Российская газета. - 2012. - № 251.
} 


\section{Право и политика $6(162) \cdot 2013$}

При определении размера компенсации вреда должны учитываться требования разумности и справедливости. В тоже время, характер физических и нравственных страданий оценивается судом с учетом фактических обстоятельств, при которых был причинен моральный вред. Суд может уменьшить размер возмещения вреда, причиненного гражданином, с учетом его имущественного положения, за исключением случаев, когда вред причинен действиями, совершенными умышленно, с учетом вины потерпевшего 4 .

Правила определения размера компенсации морального вреда, изложенные в Постановлениях Пленума Верховного Суда Российской Федерации, в большинстве своем, дублируют нормы Гражданского кодекса Российской Федерации ${ }^{5}$ При этом установлены и дополнительные критерии, оцениваемые судом:

- какие нравственные или физические страдания перенесены потерпевшим ${ }^{6}$;

- в какой сумме потерпевший оценивает компенсацию физических и (или) нравственных страданий ${ }^{7}$;

- подлежащая взысканию сумма компенсации морального вреда должна быть соразмерна причиненному вреду ${ }^{8}$.

В научной литературе на предмет достаточности критериев и необходимости применения судейского

${ }^{4}$ П. 3 ст. 1083 Гражданского кодекса Российской Федерации // СЗ РФ. - 1996. - № 5. - ст. 410.

${ }^{5}$ См.: Постановление Пленума Верховного Суда РФ от 20.12.1994 № 10 (ред. от 06.02.2007) «Некоторые вопросы применения законодательства о компенсации морального вреда» // Российская газета. - 1995. - № 29; Постановление Пленума Верховного Суда РФ от 26.01.2010 № 1 «О применении судами гражданского законодательства, регулирующего отношения по обязательствам вследствие причинения вреда жизни или здоровью гражданина» // Российская газета. - 2010. - № 24; Постановление Пленума Верховного Суда Российской Федерации от 24 февраля 2005 г. № 3 «О судебной практике по делам о защите чести и достоинства граждан, а также деловой репутации граждан и юридических лиц» // Российская газета. - 2005. - № 50; Постановление Пленума Верховного Суда РФ от 18 октября 2012 г. № 21 «О применении судами законодательства об ответственности за нарушения в области охраны окружающей среды и природопользования» // Российская газета. - 2012. - № 251.

${ }^{6}$ П. 44 Постановления Пленума Верховного Суда РФ от 18 октября 2012 г. № 21 «О применении судами законодательства об ответственности за нарушения в области охраны окружающей среды и природопользования» // Российская газета. - 2012. - № 251.

7 П. 44 Постановления Пленума Верховного Суда РФ от 18 октября 2012 г. № 21 «О применении судами законодательства об ответственности за нарушения в области охраны окружающей среды и природопользования» // Российская газета. - 2012. - № 251.

${ }^{8}$ П. 15 Постановления Пленума Верховного Суда Российской Федерации от 24 февраля 2005 г. № 3 «О судебной практике по делам о защите чести и достоинства граждан, а также деловой репутации граждан и юридических лиц» // Российская газета. - 2012. - № 251. усмотрения в процессе определения размера компенсации морального вреда встречаются различные позиции исследователей. Одни специалисты полагают, что «общие положения о возмещении морального вреда явно недостаточны», целесообразно разработать «типовые методики определения размера морального вреда ${ }^{9}$, представленные же законом критерии «носят весьма общий и обтекаемый характер и в случае необходимости предоставляют практически неограниченный простор свободному усмотрению судьи, никак не скованному никакими пределами присуждаемой денежной компенсации», что стало порождать «явно несправедливые с точки зрения пострадавших, так и здравого смысла судебные решения» ${ }^{10}$. Другие считают, что законодатель, по существу, «отказался регулировать размер денежной компенсации морального вреда, оставив решение этого вопроса на усмотрение суда»" ${ }^{11}$ «возникающие в практике судебного разбирательства вопросы о размере компенсации должны быть в целях единообразия в определенной форме унифицированы»и не зависеть от судейского усмотрения ${ }^{12}$.

Необходимым является исследование каждого критерия, имеющего значение для определения размера компенсации морального вреда, причиняемого вследствие экологических правонарушений.

Как уже говорилось, критерий «характер и степень причиненных потерпевшему физических и нравственных страданий» оценивается с учетом «индивидуальных особенностей потерпевшего», «фактических обстоятельств, при которых был причинен моральный вред» и «других конкретных обстоятельств, свидетельствующих о тяжести перенесенных им страданий». Справедливо замечено, такой критерий «представляется наиболее сложным, поскольку, является составным (суду помимо степени и характера физических и нравственных страданий необходимо оценить фактические обстоятельства, при которых был причинен моральный вред, и индивидуальные особенности потерпевшего), имеет больше психологический, нежели правовой аспект. Положение усложняется еще

\footnotetext{
9 Петров М. Правовые аспекты защиты прав потребителей // Российская юстиция, 1994. - № 2. - С. 29-30.

${ }^{10}$ Нарижный С. В. Компенсация морального вреда в уголовном судопроизводстве России. - СПб.: «Издательский дом Герда», 2001. - C. 156-157.

${ }^{11}$ Трунова Л. К. Гражданский иск о компенсации морального вреда в уголовном судопроизводстве. Дисс. ... канд. юрид. наук. - М., 1999. - C. 110-111.

${ }^{12}$ Скачкова Г. С. Проблемы возмещения морального вреда в сфере трудовых отношений // Юридический мир, 1997. № 6-7. - C. 59-60.
} 
и тем, что на законодательном уровне не определены понятия «степень страдания», «характер страдания» и единицы их измерения» ${ }^{13}$.

Обращает на себя внимание аналогичный критерий оценки размера компенсации морального вреда, предложенный Пленумом Верховного Суда Российской Федерации «О применении судами законодательства об ответственности за нарушения в области охраны окружающей среды и природопользования» - «какие нравственные или физические страдания перенесены потерпевшим» ${ }^{14}$, который отражает содержание категории «характер страданий». Однако степень страданий этим критерием не оценивается, хотя экогенный вред в своей массе имеет латентный характер, когда «можно с большой степенью вероятности предположить его накопление, но невозможно определить объем из-за невыраженности проявления» ${ }^{15}$.

На определение размера компенсации морального вреда физические и нравственные страдания влияют как раздельно друг от друга, так и в совокупности, в зависимости от того какие страдания испытывает человек в результате экологических правонарушений.

Н. Уюткин отмечает, что степень страданий и их проявление подлежат безусловной дифференцированной оценке судьями ${ }^{16}$. Показательны положения ряда методических указаний: боль может быть разделена на слабую, умеренную, сильную, очень сильную ${ }^{17}$; тошнота может быть легкой ${ }^{18}$, выражаться умеренной

13 Редько Е. П. Компенсация морального вреда как способ защиты гражданских прав. Дисс. ... канд. юрид. наук. - Абакан, 2009. - C. 99.

14 П. 44 Постановление Пленума Верховного Суда РФ от 18 октября 2012 г. № 21 «О применении судами законодательства об ответственности за нарушения в области охраны окружающей среды и природопользования» // Российская газета. - 2012. - № 251.

${ }^{15}$ Велиева Д. С. Система конституционных экологических прав и обязанностей в Российской Федерации // [Электронный ресурс]. Доступ из справ.-правовой системы «Гарант». Дата обращения: 01.05.2013.

${ }^{16}$ Уюткин Н. Проблемные вопросы компенсации морального вреда в судебной практике // Судья, 2006. - №. 9. - С. 52.

${ }^{17}$ Методические указания № 2001/29 «Порядок и сроки назначения наркотических анальгетиков» (утв. Минздравом РФ 19 июля 2001 г.). Документ опубликован не был. // [Электронный ресурс]. Доступ из справ.-правовой системы «КонсультантПлюс». Дата обращения: 01.05.2013.

${ }^{18}$ Приказ Минздрава РФ от 22 октября 2003 г. № 500 «Об утверждении протокола ведения больных «Реабилитация больных наркоманией (Z 50.3)». Документ опубликован не был. // [Электронный ресурс]. Доступ из справ.-правовой системы «КонсультантПлюс». Дата обращения: 01.05.2013. рвотой, сильной рвотой ${ }^{19}$; головокружение может быть легким, умеренным, сильным ${ }^{20}$.

Под «характером физических и нравственных страданий» предлагается рассматривать вид страданий ${ }^{21}$. Полагаем, что это не только вид страдания, но и его характеристика с описанием симптоматики ${ }^{22}$.

Показательна точка зрения, что «характер физических и нравственных страданий в таком понимании можно было бы учитывать и оценивать, если бы можно было установить некое количественное соотношение между разновидностями страданий» ${ }^{23}$. Рассматривается и возможность установления зависимости между видом страдания и неблагоприятностью его последствий, классификации страданий по степени неприятности ощущений ${ }^{24}$.

В силу сложности соотношения физических и нравственных страданий, предлагается для определения размера компенсации морального вреда учитывать не вид (характер) нравственных или физических страданий, а характер и значимость тех нематериальных благ, которым причинен вред, поскольку именно их характер и значимость для человека и определяют

\footnotetext{
${ }^{19}$ Методические указания «МУ 3.4.2552-09. 3.4. Санитарная охрана территории. Организация и проведение первичных противоэпидемических мероприятий в случаях выявления больного (трупа), подозрительного на заболевания инфекционными болезнями, вызывающими чрезвычайные ситуации в области санитарноэпидемиологического благополучия населения. Методические указания» (утв. Главным государственным санитарным врачом РФ 17.09.2009). // М., Федеральный центр гигиены и эпидемиологии Роспотребнадзора, 2009.

${ }^{20}$ Мальшеев Н.А., Смагулов К. 3. и др. Методическое пособие «Цитомегаловирусная инфекция. Эпидемиология, клиника, диагностика, лечение и профилактика» (утв. Комитетом здравоохранения Правительства Москвы 7 февраля 2001 г.). - М.: ГЕОС, 2001. - $51 \mathrm{c}$

21 Эрделевский А. М. Указ соч. С. 204.

${ }^{22} \mathrm{~B}$ делах, связанных с компенсацией морального вреда учитываются жалобы истцов на ухудшение самочувствия, нарушение сна, сильную головную боль, боль в суставах, повышение артериального давления, возникшее чувство беспокойства, дискомфорта, опасения / См. Решение Ленинского районного суда г. Перми // http://www.ecopravo.seu.ru/precedent/2-39.html; Решение Смирныховского районного суда Сахалинской области от 07 февраля 2012 по делу № 2-3/2012 // ГАС «Правосудие» URL.: http:// www.sudrf.ru; Апелляционное определение Курского областного суда от 28 апреля 2012 г. по в № 33-941-2012, Определение Ленинградского областного суда от 16 августа 2012 г. № 33-3561/2012 // [Электронный ресурс]. Доступ из справ.-правовой системы «КонсультантПлюс»: Судебная практика. Дата обращения: 01.05.2013.

23 Эрделевский А. М. Указ соч. С. 205.

${ }^{24}$ Гаикий М. А. Правовое регулирование и механизм определения размера компенсации морального вреда в гражданском праве. Дисс. ... канд. юрид. наук. - М., 2006. - С. 151.
} 


\section{Право и политика $6(162) \cdot 2013$}

величину причиненного морального вреда ${ }^{25}$. Однако, говорить о «значимости» одних нематериальных благ (ценностей) перед другими следует весьма условно требуется соблюдение их баланса ${ }^{26}$.

В юридической науке предлагается исследовать продолжительность физического и (или) нравственного страдания для оценки их характера и степени ${ }^{27}$. По делам о компенсации морального вреда, причиненного вследствие экологических правонарушений, этот критерий заслуживает особого внимания, поскольку в силу высокой латентности экологических правонарушений, последствия которых имеют значительный временной период, моральный вред может носить длительный характер ${ }^{28}$.

При этом на характер и степень физических и нравственных страданий влияют индивидуальные особенности потерпевщего. Очевидным представляется, что на степень и характер физических и (или) нравственных страданий могут влиять пол, раса, национальность, возраст, состояние здоровья, психическое состояние, интеллектуальное развитие. Действительно, в возникновении и развитии различных страданий существенную, а иногда и определяющую роль играют их личностные особенности. Одно и то же повреждающее воздействие у разных людей может вызвать неодинаковые последствия ${ }^{29}$.

Заметим, что законодатель не устанавливает, какие именно индивидуальные особенности потерпевшего могут влиять на степень и характер физических и нравственных страданий, соответственно, их перечень открытый, учитывается лишь их юридическое значение. В этой связи интерес вызывает классификация индивидуальных характеристик потерпевшего на: юридически значимые - признаки, наличие

\footnotetext{
${ }^{25}$ Гаичкий М. А. Там же.
}

${ }^{26}$ См.: Постановление Конституционного Суда РФ от 14.05.2009г. № 8-П «По делу о проверке конституционности положения подпункта «б» пункта 4 Постановления Правительства Российской Федерации «Об утверждении Порядка определения платы и ее предельных размеров за загрязнение окружающей природной среды, размещение отходов, другие виды вредного воздействия» в связи с запросом Верховного суда Республики Татарстан» // СЗ РФ. - 2009. - № 22. - ст. 2752.

${ }^{27}$ Гаикий М. А. Указ. соч. С. 152.

${ }^{28}$ См. Определение Ленинградского областного суда от 16 августа 2012 г. № 33-3561/2012 // [Электронный ресурс]. Доступ из справ.правовой системы «КонсультантПлюс»: Судебная практика. Дата обращения: 01.05.2013; Решение Сегежского городского районного суда Республики Карелия; Решение Северского городского суда Томской области // http://www.ecopravo.seu.ru/precedent/2-39.html.

${ }^{29}$ См.: Дашкина Э. Ш., Володина С. И. Использование адвокатом специальных знаний в области психологии по оценке нравственных страданий (на примере диффамационных споров) // Адвокатская практика, 2006. - № 6. - С. 10. которых всегда усиливает нравственные и физические страдания, и в силу этого, безусловно, должны учитываться при любых обстоятельствах (болезнь, наличие увечья, преклонный возраст, беременность); - признаки, которые при любых обстоятельствах уменьшают силу страданий при причинении морального вреда (состояние алкогольного, наркотического опьянения); - признаки, наличие которых усиливает или уменьшает страдания человека при причинении морального вреда только при определенных обстоятельствах (состояние аффекта); - признаки, которые исключительно в ситуации конкретного правонарушения или преступления могут усиливать или ослабить страдания потерпевшего (множественность стрессов на определенном временном отрезке, предшествующий травматический опыт), и юридические безразличные - наличие или отсутствие которых никогда не влияет на силу переживаний человека, связанных с причинением ему морального вреда, и которые не могут учитываться при определении размера компенсации (группа крови, цвет глаз и т.д.) ${ }^{30}$.

Фактические обстоятельства, при которых был причинен моральный вред, - не менее важный критерий для оценки степени и характера физических и нравственных страданий, причиненных в результате экологических правонарушений.

Справедливо отмечено, что «учитывать в целях определения размера компенсации следует не все фактические обстоятельства, а только заслуживающие внимания для определения размера компенсации. Их перечень дифференцируется в зависимости от вида неимущественных благ, затронутых правонарушением» ${ }^{31}$. Полагаем, что под заслуживающими внимания фактическими обстоятельствами, следует понимать время, место, способ, обстановку и другие факультативные признаки объективной стороны экологического правонарушения $^{32}$.

\footnotetext{
${ }^{30}$ См. об этом: Будякова Т. П. Индивидуальные особенности потерпевшего как критерий степени физических и нравственных страданий // Российская юстиция, 2003. - № 2. - С. 15-16.

${ }^{31}$ Редько Е. П. Указ соч. С. 101.

${ }^{32}$ При определении размеров компенсации морального вреда суды учитывают обстоятельства, создающие антисанитарные условия, которые препятствуют использованию земельного участка по назначению, влияют на окружающую среду, создают угрозу здоровью неопределенного круга лиц, нарушают конституционное право человека на благоприятную окружающую среду // См. Апелляционное определение Верховного Суда Республики Саха (Якутия) от 3 октября 2012 г. по делу № 33-3377/12 // [Электронный ресурс]. Доступ из справ.-правовой системы «КонсультантПлюс»: Судебная практика. Дата обращения: 01.05.2013.; Решение Нерчинского районного суда (Забайкальский край) от 19.03.2011 г. // [Электронный pecypc]. Доступ из справ.-правовой системы «Право.ru»: Судебная практика. Дата обращения: 01.05.2013.
} 
«Другие конкретные обстоятельства, свидетельствующие о тяжести перенесенных потерпевшим страданий»-широко толкуемый критерий, с помощью которого суд также устанавливает характер и степень физических или нравственных страданий. Это могут быть: действия, которые пришлось предпринимать потерпевшим, чтобы предотвратить последствия экологического правонарушения, в результате которого причиняется моральный вред, сгладить последствия физических и (или) нравственных страданий, на какие лишения необходимо было «пойти» ради этого. Не случайно суды учитывают обстоятельства, препятствующие восстановлению физического и (или) нравственного благополучия потерпевшего после экологического правонарушения ${ }^{33}$.

Оценивая степень вины причинителя вреда в случаях, когда вина является основанием компенсации морального вреда, необходимо руководствоваться тем, что «суд всегда должен учитывать наличие или отсутствие вины причинителя вреда, а при наличии вины - учитывать ее степень» ${ }^{34}$. По нашему мнению, форма вины причинителя вреда выступает критерием для определения размера компенсации морального вреда: небрежность определяет меньший ее размер, нежели легкомыслие ${ }^{35}$. Это правило действует при прочих одинаковых условиях. В совокупности со степенью вины причинителя вреда суд устанавливает и вину потерпевшего.

\footnotetext{
${ }^{33}$ Судами устанавливались факты - дополнительные физические и нравственные страдания возникли в результате: отказа восстановить плодородный слой почвы, нарушенный загрязнением; запрета выпаса скота из-за длительного времени дезактивации усадеб и огородов, невозможности использования приусадебных участков по их прямому назначению и т.п. / См. Решение Ревдинского районного суда Свердловской области от 09.06.2011 г. по делу № 2-133/2011// [Электронный ресурс]. Доступ из справ.-правовой системы «Право.ru»: Судебная практика. Дата обращения: 01.05.2013; Кассационное определение Судебной коллегии по гражданским делам Верховного Суда РФ от 8 января 2002 г. № 88-Г01-7 // [Электронный ресурс]. Доступ из справ.правовой системы «КонсультантПлюс»: Судебная практика. Дата обращения: 01.05.2013.
}

${ }^{34}$ Дашко О. В. Моральный вред и особенности его компенсации за нарушение авторских и смежных прав. Дисс. ... канд. юрид. наук. - М., 2006. - С. 92.

${ }^{35}$ Предлагается, чтобы Верховный Суд Российской Федерации в соответствующем постановлении Пленума установил доли (проценты), в пределах которых может быть взыскана компенсация (при умышленной вине $-100 \%$, легкомыслии $-50 \%$, небрежности- 20\%). Критика же этого предложения основывается на том, что российское законодательство еще не унифицировано по формам вины, а также отсутствует строго закрепленный размер компенсации морального вреда в зависимости от вида правонарушения / См. об этом: Редько Е. П. Указ. соч. С. 98.
Следует обратить внимание, что критерий «другие конкретные обстоятельства, свидетельствующие о тяжести перенесенных потерпевшим страданий»не может быть заменен критерием «иные заслуживающие внимание обстоятельства», который подразумевает наличие широко круга обстоятельств, оказывающих влияние на размер компенсации морального вреда в силу того, что они заслуживают внимания. Наличие такого критерия для определения размера компенсации морального вреда в законодательстве является оправданным, так как исчерпывающе определить этот перечень не представляется возможным. Подчеркивается, что главное требование, предъявляемое к критериям определения размера компенсации - это их объективность ${ }^{36}$.

Под иными заслуживающими внимания обстоятельствами, оцениваемыми при определении размера компенсации морального вреда, причиненного вследствие экологических правонарушений, следует понимать: длящийся характер физических и (или) нравственных страданий, количество нарушенных нематериальных ценностей, восстановимость нарушенных благ ${ }^{37}$.

Предлагается принимать во внимание и субъективные аспекты, как прямо закрепленные в законе (индивидуальные особенности потерпевшего), так и иные - общественную оценку фактического обстоятельства (обстоятельств), вызвавшего вред ${ }^{38}$; область

${ }^{36}$ Михно Е. А. Компенсация морального вреда во внедоговорных обязательствах. Дисс. ... канд. юрид. наук. - СПб., 1998. - С. 32.

37 Показательно, что при определении размера компенсации морального вреда Европейским Судом по правам человека учитываются: продолжительность негативного воздействия окружающей среды на человека; вид негативного воздействия; степень и характер заболеваний; степень и характер физических и (или) нравственных страданий (отсутствие сна, испытываемые чувства заявителей - горе, беспокойство, расстройство, неуверенность) / См. Дело «MARTÍNEZ против Испании» (Жалоба № 61654/08); Дело «DEÉS против Венгрии» (Жалоба № 2345/06). Дело «GIACOMELLI против Италии» (Жалоба № 59909/00). Дело «GUERRA и другие против Италии» (Жалоба № 116/1996/735/932). Дело «TAŞKIN и другие против Турции» (Жалоба № 46117/99). // http://hudoc.echr.coe.int. Дата обращения: 01.05.2013.

38 По таким делам Европейский Суд по правам человека исходит из соотношения экономических, экологических, социальнополитических интересов государства, общества, граждан / См. Дело «FREDIN против Швеции (№. 1)» (Жалоба № 12033/86); Дело «POWELL и RAYNER против Соединенного Королевства» (Жалоба № 9310/81); Дело «POWELL и RAYNER против Соединенного Королевства» (Жалоба № 9310/81); (Дело «Нatton и другие против Соединенного Королевства Великобритании и Северной Ирландии», жалоба № 36022/97); Дело «ZAMMIT MAEMPEL против Мальты» (Жалоба № 24202/10). Дело «LÓPEZ OSTRA против Испании» (Жалоба № 16798/90). // http://hudoc.echr. coe.int. Дата обращения: 01.05.2013. 


\section{Право и политика 6 (162) • 2013}

распространения сведений о происшедшем событии ${ }^{39}$; материальное и социальное положение сторон; местные условия и нравы ${ }^{40}$; биопсихосоциальные связи человека с окружающей средой ${ }^{41}$.

В нашем случае под местными условиями следует понимать, в том числе, состояние (благоприятность) окружающей среды в соответствующем регионе ${ }^{42}$. Необходимо оценивать как региональный природоресурсный потенциал - способность всех компонентов природных ресурсов (с учетом их состояния, месторасположения и других характеристик) обеспечивать собственное воспроизводство и восстановление, производство продуктов и услуг, поддержание соответствующих условий жизнедеятельности населения ${ }^{43}$, так и рекреационный потенциал - свойство природной территории оказывать на человека положительное физическое, психическое воздействие 44 . Биопсихосоциальные же связи человека с окружающей средой характеризуют не только

\footnotetext{
${ }^{39}$ См. об этом.: Малеина М. Н. Личные неимущественные права граждан: понятие, осуществление, защита. - 2-е изд., испр. и доп. - М.: М3 Пресс, 2001. - С. 42.

${ }^{40}$ См.: Гаиякий М. А. Указ. соч. С. 121.

${ }^{41}$ См.: Горшенков Г. Г. Указ. соч. С. 106.
}

42 Так на территории ПФО в 2010 г. поступило от стационарных источников в атмосферный воздух 2,5 млн. т загрязняющих веществ. По объему выбросов вредных веществ в атмосферу от стационарных источников лидирует Оренбургская область (616,5 тыс. т, или 24,5\% валовых выбросов от стационарных источников в ПФО). Крупные промышленные центры, оказывающие неблагоприятное воздействие на качество атмосферного воздуха, сосредоточены в Республике Башкортостан (387,6 тыс. т, $15,4 \%)$, Пермском крае (324,6 тыс. т, 12,9\%), Самарской области (308,5 тыс. т, 12,3\%). В 2011 году потупило от стационарных источников в атмосферный воздух 2,6 млн. т. загрязняющих веществ. Объем сброса загрязненных сточных вод в поверхностные водные объекты увеличился на 13\% (3028,38 млн. м $^{3}$ ) по сравнению с 2009 г. (2674,40 млн. м³). В Самарской области этот показатель увеличился на 72\%, Ульяновской - на $35 \%$, Кировской - на 34\%. В 2010 г. по объему сброса загрязненных сточных вод в поверхностные водные объекты лидируют Республика Татарстан (434,86 млн. м $\left.{ }^{3}\right)$ и Самарская область (697,00 млн. м³ См. Государственный доклад «О состоянии и об охране окружающей среды Российской Федерации в 2010 году» С. 356-357. Государственный доклад «О состоянии и об охране окружающей среды Российской Федерации в 2011 году» С. 180.

43 Такая способность оценивается с позиции обеспечения условий жизни и деятельности людей (производственной и непроизводственной), естественного воспроизводства и восстановления природных компонентов / Курс социально-экономической статистики: Учебник для вузов / Под ред. проф. М.Г. Назарова. - М.: Финстатинформ, ЮНИТИ-ДАНА, 2000. - С. 273-274.

${ }^{44}$ Рюмин В. В. Опыт оценки природного потенциала ландшафта // География и природные ресурсы, 1984. - № 4. - С. 125-131; Экологический словарь. [Электронный доступ]: http:/dic.academic. ru/contents.nsf/ecolog/ Дата обращения - 08.02.2013 г. «взаимоотношения» индивидуума с окружающей средой, но и ее восприятие ${ }^{45}$.

Оценочный характер носит критерий «разумности u справедливости», который взаимосвязан с «имущчественным положением гражданина - причинителя вреда» и «соразмерностью взысканной суммы компенсации морального вреда причиненному вреду».

Требованием разумности и справедливости считается «обращенное к суду требование о соблюдении разумных и справедливых соотношений по разным делам размеров компенсации морального вреда» ${ }^{46}$, в числе которых и дела о компенсации морального вреда, причиненного вследствие экологических правонарушений ${ }^{47}$.

Требование справедливости означает беспристрастность, истинность и правильность решения, принятие которого осуществляется на законных основания ${ }^{48}$. В тоже время считается, что «цель специального законодательного обращения к требованиям разумности и справедливости заключается в том, чтобы адекватно оценить моральные страдания при определении размера компенсации морального вреда» ${ }^{49}$.

В контексте разумного и справедливого определения размера компенсации морального вреда, следует исследовать и критерий, предполагающий учет «uмyщественного положения гражданина - причинителя

\footnotetext{
${ }^{45}$ См. Бринчук М. М. Экологическое право: Учебник. - 2-е изд., перераб. и доп. - М.: Юристь, 2004. - С. 31-35; Вернадский В. И. Биосфера и ноосфера. М.: Наука. 1989. - 258 с.; Голиченков А. К. Экологическое право России: словарь юридических терминов: Учебное пособие для вузов. 2-е изд., перераб. и доп. - М.: Издательский Дом «Городец», 2012. - 512 с. и др..
}

${ }^{46}$ Редько Е. П. Указ. соч. С. 105-106.

${ }^{47}$ См.: Апелляционное определение Курского областного суда от 28 апреля 2012 г. по делу № 33-941-2012; Определение Ленинградского областного суда от 16 августа 2012 г. № 33-3561/2012 // [Электронный ресурс]. Доступ из справ.-правовой системы «КонсультантПлюс»: Судебная практика. Дата обращения: 01.05.2013; Определение Санкт-Петербургского городского района от 8 июля 2010 г. // // [Электронный ресурс]. Доступ из справ.правовой системы «Гарант»: Судебная практика. Дата обращения: 01.05.2013.

48 Показательно, что компенсация морального вреда при нарушении права каждого на благоприятную окружающую среду осуществляется по правилам ст. 41 «Справедливая компенсация» Конвенции о защите прав человека и основных свобод / См:. Конвенция о защите прав человека и основных свобод (Заключена в г. Риме 04.11.1950) (с изм. от 13.05.2004) (вместе с «Протоколом [№ 1]» (Подписан в г. Париже 20.03.1952), «Протоколом № 4 об обеспечении некоторых прав и свобод помимо тех, которые уже включены в Конвенцию и первый Протокол к ней» (Подписан в г. Страсбурге 16.09.1963), «Протоколом № 7» (Подписан в г. Страсбурге 22.11.1984) // Бюллетень международных договоров. - 2001. - № 3.

49 Дашко О. В. Указ. соч. С. 100. 
вреда». В. В. Владимирова полагает, что разумность не должна ставиться в зависимость от критерия имущественного положения причинителя вреда, поскольку получение достойной, на взгляд потерпевшего, компенсационной суммы есть достижение справедливости ${ }^{50}$. Противоположной позиции придерживается Г. М. Резник, считающий, что требование разумности и справедливости разумно включает в себя учет имущественного положения причинителя вреда ${ }^{51}$.

На наш взгляд, суд, определяя размер компенсации морального вреда, причиненного вследствие экологических правонарушений, не должен принимать во внимание имущественное положение причинителя вреда. Представляется спорным и утверждение о том, что если ответчик будет выплачивать денежную сумму в течение нескольких лет небольшими суммами, то значение и актуальность самой компенсации будет утрачена ${ }^{52}$.

Соразмерность взысканной суммы компенсации морального вреда причиненному моральному вреду - еще один оценочный критерий, который взаимосвязан с требованием разумности и справедливости. Большинство граждан считает, что чем выше размер, взысканный судом с нарушителя, тем уважительнее относится государство к его нарушенным правам. Представляется, что крайне малый размер компенсации, действительно «смешон в глазах общества и государства» и унижает истца ${ }^{53}$. В свою очередь, полагаем, что моральный вред, причиненный вследствие экологических правонарушений, может явиться одним из высоко оцениваемых в денежном эквиваленте: такие правонарушения, затрагивая биологические и экологические начала существования человека, изменяя его геном, посягают на основы его жизнедеятельности.

\section{Библиография:}

1. Конвенция о защите прав человека и основных свобод (Заключена в г. Риме 04.11.1950) (с изм. от 13.05.2004) (вместе с «Протоколом [№ 1]» (Подписан в г. Париже 20.03.1952), «Протоколом № 4 об обеспечении некоторых прав

50 Владимирова B. В. Компенсация морального вреда - мера реабилитации потерпевшего в российском уголовном процессе. - М.: Волтерс Клувер, 2007. - С. 135.

${ }^{51}$ Комментарий к Гражданскому кодексу Российской Федерации: в 3 т. Т. 2. Комментарий к Гражданскому кодексу Российской Федерации, части второй / Под ред. Т. Е. Абовой, А. Ю. Кабалкина. - 3-е изд., перераб. и доп. - М.: Юрайт-Издат, 2006. - С. 1151.

${ }^{52}$ Дашко О. В. Указ. соч. С. 105.

${ }^{53}$ Дашко О. В. Указ. соч. С. 101. и свобод помимо тех, которые уже включены в Конвенцию и первый Протокол к ней» (Подписан в г. Страсбурге 16.09.1963), «Протоколом № 7» (Подписан в г. Страсбурге 22.11.1984) // Бюллетень международных договоров. - 2001. - № 3;

2. Гражданский кодекс Российской Федерации (часть вторая) от 26.01.1996 № 14-Ф3 // С3 РФ. 1996. - № 5. - ст. 410;

3. Постановление Конституционного Суда РФ от 14.05.2009 № 8-П «По делу о проверке конституционности положения подпункта «б» пункта 4 Постановления Правительства Российской Федерации «Об утверждении Порядка определения платы и ее предельных размеров за загрязнение окружающей природной среды, размещение отходов, другие виды вредного воздействия» в связи с запросом Верховного суда Республики Татарстан» // С3 РФ. - 2009. - № 22. - ст. 2752.

4. Постановление Пленума Верховного Суда РФ от 20.12.1994 № 10 (ред. от 06.02.2007) «Некоторые вопросы применения законодательства о компенсации морального вреда» // Российская газета. - 1995. - № 29;

5. Постановление Пленума Верховного Суда РФ от 26.01.2010 № 1 «О применении судами гражданского законодательства, регулирующего отношения по обязательствам вследствие причинения вреда жизни или здоровью гражданина» // Российская газета. - 2010. - № 24;

6. Постановление Пленума Верховного Суда Российской Федерации от 24.02.2005 № 3 «О судебной практике по делам о защите чести и достоинства граждан, а также деловой репутации граждан и юридических лиц» // Российская газета. - 2005. - № 50;

7. Постановление Пленума Верховного Суда РФ от 18.10.2012 № 21 «О применении судами законодательства об ответственности за нарушения в области охраны окружающей среды и природопользования» // Российская газета. - 2012. - № 251;

8. Государственный доклад «О состоянии и об охране окружающей среды Российской Федерации в 2011 году». Доклад размещен на сайте Министерства природных ресурсов и экологии Российской Федерации http://www.mnr.gov.ru // URL: http:// www.mnr.gov.ru/regulatory/list.php?part =1101 Дата обращения 01.05.2013;

9. Бринчук М. М. Экологическое право (право окружающей среды). - 2-е изд., перераб. и доп. - М.: Юристь, 2003. - 670 с.;

10. Будякова Т. П. Индивидуальные особенности потерпевшего как критерий степени физических и 


\section{Право и политика 6 (162) 2013}

нравственных страданий // Российская юстиция, 2003. - № 2. - С. 15-16;

11. Велиева Д. С. Система конституционных экологических прав и обязанностей в Российской Федерации // [Электронный ресурс]. Доступ из справ.-правовой системы «Гарант». Дата обращения: 01.05.2013.

12. Вернадский В. И. Биосфера и ноосфера. - М.: Наука, 1989. - 262 с.;

13. Владимирова В. В. Компенсация морального вредамера реабилитации потерпевшего в российском уголовном процессе. - М.: Волтерс Клувер, 2007. - 176 с.;

14. Гацкий М. А. Правовое регулирование и механизм определения размера компенсации морального вреда в гражданском праве. Дисс. ... канд. юрид. наук. - М., 2006. - 185 с.;

15. Горшенков Г. Г. Моральный вред и его компенсация по российскому законодательству. Дисс. ... канд. юрид. наук. - Новгород, 1990. - 165 с.;

16. Дашкина Э. Ш., Володина С. И. Использование адвокатом специальных знаний в области психологии по оценке нравственных страданий (на примере диффамационных споров) // Адвокатская практика, 2006. - № 6. - С. 7-17;

17. Дашко О. В. Моральный вред и особенности его компенсации за нарушение авторских и смежных прав. Дисс. ... канд. юрид. наук. - М., 2006. - 207 с.;

18. Комментарий к Гражданскому кодексу Российской Федерации: в 3 т. Т. 2. Комментарий к Гражданскому кодексу Российской Федерации, части второй / Под ред. Т. Е. Абовой, А. Ю. Кабалкина. - 3-е изд., перераб. и доп. - М.: Юрайт-Издат, 2006. - 1192 с.;

19. Курс социально-экономической статистики: Учебник для вузов / Под ред. проф. М. Г. Назарова. М.: Финстатинформ, ЮНИТИ-ДАНА, 2000. - 771 с.;

20. Малеина М. Н. Личные неимущественные права граждан: понятие, осуществление, защита. - 2-е изд., испр. и доп. - М.: М3 Пресс, 2001. - 244 с.;

21. Михно Е. А. Компенсация морального вреда во внедоговорных обязательствах. Дисс. ... канд. юрид. наук. - СПб., 1988. - 162 с.;

22. Нарижный С. В. Компенсация морального вреда в уголовном судопроизводстве России. - СПб.: «Издательский дом Герда», 2001. - 288 с.;

23. Петров М. Правовые аспекты защиты прав потребителей // Российская юстиция. - 1994. - № 2. - С. 28-30;

24. Редько Е. П. Компенсация морального вреда как способ защиты гражданских прав. Дисс. ... канд. юрид. наук. - Абакан, 2009. - 207 с.;

25. Скачкова Г. С. Проблемы возмещения морального вреда в сфере трудовых отношений // Юридический мир, 1997. - № 6-7. - С. 55-62;
26. Трунова Л. К. Гражданский иск о компенсации морального вреда в уголовном судопроизводстве. Дисс. ... канд. юрид. наук. - М., 1999. - 261 с.;

27. Уюткин Н. Проблемные вопросы компенсации морального вреда в судебной практике // Судья, 2006. - №. 9. - С. 50-52;

28. Эрделевский А. М. Компенсация морального вреда // Анализ и комментарий законодательства и судебной практики (3-е издание). - М.: Волтерс Клувер, 2007. - 320 с.

\section{References (transliteration):}

1. Brinchuk M. M. Ekologicheckoe pravo (pravo okruzhayuschey sredy). - 2-e izd., pererab. i dop. - M.: Yurist', 2003. - 670 s.;

2. Budyakova T. P. Individual'nye osobennosti poterpevshego kak kriteriy stepeni fizicheskih i nravstvennyh stradaniy // Rossiyskaya yusticiya, 2003. № 2. - S. 15-16;

3. Velieva D. S. Sistema konstitucionnyh ekologicheskih prav i obyazannostey v Rossiyskoy Federacii // [Elektronnyy resurs]. Dostup iz sprav.-pravovoy sistemy «Garant». Data obrascheniya: 01.05.2013.

4. Vernadskiy V. I. Biosfera i noosfera. - M.: Nauka, 1989. - 262 s.;

5. Vladimirova V. V. Kompensaciya moral'nogo vreda - mera reabilitacii poterpevshego v rossiyskom ugolovnom processe. - M.: Volters Kluver, 2007. - 176 c.;

6. Gackiy M. A. Pravovoe regulirovanie i mehanizm opredeleniya razmera kompensacii moral'nogo vreda $\mathrm{v}$ grazhdanskom prave. Diss. ... kand. yurid. nauk. M., 2006. - 185 c.;

7. Gorshenkov G. G. Moral'nyy vred i ego kompensaciya po rossiyskomu zakonodatel'stvu. Diss. ... kand. yurid. nauk. - Novgorod, 1990. - 165 c.;

8. Dashkina E. Sh., Volodina S. I. Ispol'zovanie advokatom special'nyh znaniy v oblasti psihologii po ocenke nravstvennyh stradaniy (na primere diffamacionnyh sporov) // Advokatskaya praktika, 2006. - № 6. - S. 7-17;

9. Dashko O. V. Moral'nyy vred i osobennosti ego kompensacii za narushenie avtorskih i smezhnyh prav. Diss. ... kand. yurid. nauk. - M., 2006. - 207 c.;

10. Kurs social'no-ekonomicheskoy statistiki: Uchebnik dlya vuzov / Pod red. prof. M. G. Nazarova. - M.: Finstatinform, YuNITI-DANA, 2000. - 771 c.;

11. Maleina M. N. Lichnye neimuschestvennye prava grazhdan: ponyatie, osuschestvlenie, zaschita. 2-e izd., ispr. i dop. - M.: MZ Press, 2001. - 244 c.;

12. Mihno E. A. Kompensaciya moral'nogo vreda vo vnedogovornyh obyazatel'stvah. Diss. ... kand. yurid. nauk. - SPb., 1988. - 162 c.; 
Человек и окружающая среда

13. Narizhnyy S. V. Kompensaciya moral'nogo vreda v ugolovnom sudoproizvodstve Rossii. - SPb.: «Izdatel'skiy dom Gerda», 2001. - 288 c.;

14. Petrov M. Pravovye aspekty zaschity prav potrebiteley // Rossiyskaya yusticiya. - 1994. - № 2. - S. 28-30;

15. Red'ko E. P. Kompensaciya moral'nogo vreda kak sposob zaschity grazhdanskih prav. Diss. ... kand. yurid. nauk. - Abakan, 2009. - 207 c.;

16. Skachkova G. S. Problemy vozmescheniya moral'nogo vreda v sfere trudovyh otnosheniy // Yuridicheskiy mir, 1997. - № 6-7. - S. 55-62;
17. Trunova L. K. Grazhdanskiy isk o kompensacii moral'nogo vreda v ugolovnom sudoproizvodstve. Diss. ... kand. yurid. nauk. - M., 1999. -261 c.;

18. Uyutkin N. Problemnye voprosy kompensacii moral'nogo vreda v sudebnoy praktike // Sud'ya, 2006. - №. 9. - S. 50-52;

19. Erdelevskiy A. M. Kompensaciya moral'nogo vreda // Analiz i kommentariy zakonodatel'stva i sudebnoy praktiki (3-e izdanie). - M.: Volters Kluver, 2007. $320 \mathrm{c}$. 